\title{
Introduction: Operationalisation of Hybrid Peacebuilding in Asia
}

\section{Yuji Uesugi}

\section{Overview OF THE BOOK}

This study expands on the recent discussion presented in Hybrid Peacebuilding in Asia (Uesugi 2020) which examined complex processes of negotiated and/or mediated hybridisation shaped through interactions among myriad of stakeholders including local, national, regional and international actors. While the focus of this study is related closely to the key arguments presented in the aforementioned study, it constitutes a stand-alone academic work seeking to revitalise the reappraised discussion on hybridity and peacebuilding led by Mac Ginty and Richmond (2016) from a distinctive angle of Asia.

The study does this in three ways. The first approach explores, both conceptually and empirically, the roles of both inside and outside peacebuilders in the process of hybridisation, which can be formed through an interplay between actors operating in the 'mid-space' or space between contending parties, between national and sub-national levels,

\footnotetext{
Y. Uesugi $(\bowtie)$

Waseda University, Tokyo, Japan

e-mail: uesugi@waseda.jp

(C) The Author(s) 2021

Y. Uesugi et al. (eds.), Operationalisation of Hybrid Peacebuilding in Asia, Security, Development and Human Rights in East Asia, https://doi.org/10.1007/978-3-030-67758-9_1
} 
and between insiders and outsiders (Uesugi 2020). The second approach adopts theoretical insights gained from the existing studies on 'complexity' and 'identity' as well as critical perspectives gained from the feminist approach to the notion of 'hybridity' as a step towards transforming it from a descriptive lens to a more analytical one so that it can better inform the practice of peacebuilding. The third approach enriches our understanding of the role of 'mid-space gatekeepers', who hold a key to contesting, adopting and adapting norms brought from outside, by drawing upon identity theories emphasising the significance of the process of 'othering' (Berreby 2008). By focusing on contextually unique midspace actors in Asia, such as Buddhist monks and hybridised civil society organisations, it unpacks our presumed understanding about potential peacebuilders. The combined insights of the three approaches indicate that to operationalise hybrid peacebuilding theory, the analysis should not be limited to actors or agencies of peacebuilding but it should include their 'intersectionality' as underlying assumptions of complexity and identity stress the importance of relational aspects in a hybrid encounter. It is difficult to appreciate the process of hybridisation without grasping relationships which are fluid like a cascade.

To complement the abovementioned theoretical discussion, this study presents four empirical case studies from Asia; the first two offer insider's perspectives-Cambodia and Mindanao, the southern Philippines-and the other two provide outsider's perspectives from China and Japan. These Asian peacebuilders operate in 'statecentricity', in which national security is prioritised over realising human-centred governance (Howe 2018). It is no doubt that the rise of China as a global power is beginning to shape the rules in many areas and fields. Foreign direct investments, trade, development assistance, and peacekeeping are among few that China's influence is no longer negligible. Peacebuilding is no exception. Growing interests in the literature on the rise of China indicate that its anticipated impact on the existing norms and practices of peacebuilding could shake the foundation of the Western dominance (Lanteigne and Hirono 2012; Lee 2020).

In the context of Asia, feminist's demand for safeguarding the needs and interests of most marginalised in a peace process, and for reconceptualising the masculine structures of domination are more likely to be neglected in the discourse of hybrid peacebuilding. Non-governmental organisations (NGOs) often act as spearheads for implementing feminist's perspectives. Under the supremacy of 'statecentricity', the four 
cases in Asia-Cambodia and Mindanao as insiders and China and Japan as outsides-have revealed different styles of NGO's engagement in peacebuilding. While focusing explicitly on Asia, many of the arguments presented in this book are relevant to a general discussion surrounding the field of peacebuilding, and thus they can advance our understanding of hybrid peacebuilding both in theory and practice in Asia and beyond.

\section{Roles of OUtSIDERS IN HYBRID Peacebuilding in Asia}

This study aims to offer a better understanding of the process of hybridisation in Asian peacebuilding by looking into activities taking place sometimes strategically but often spontaneously without any coordination nor orchestration among stakeholders. This objective is pursued by focusing on undertakings in the 'mid-space'. Lately, a perspective that subscribes to the notion of 'local turn' (Mac Ginty and Richmond 2013; de Coning 2013; Randazzo 2016; Lee 2020) or 'local ownership' (Donais 2012; Lee and Özerdem 2015; Lee 2019) is dominant in both theory and practice of peacebuilding. Building upon this trend, this study explores how outsiders can engage effectively in the process of hybridisation; how they can tap into local actors and resources effectively without jeopardising local ownership or causing critical rejection by local stakeholders, both of which would damage 'locally grounded legitimacy' (Clements and Uesugi 2020) of peacebuilding intervention and thus its sustainability.

According to Bargués-Pedreny and Randazzo (2018: 1543), "hybridity requires acknowledging that peacebuilders can do little to shape the course of events." If local ownership/empowerment is a key to successfully bringing sustainable peace, it is ethically as well as practically not recommendable for outside interveners to operate with a fixed set of worldviews projected through a liberal peace paradigm. For outsiders, the question is how to address the dilemmas of hybridity or "how to maintain local political frameworks necessary for autonomy, while both reforming and working with existing power structures and identity" (Richmond 2015: 54). Thus, the major puzzle examined in this study is related to this dilemma revolving around the quest for local ownership (ibid.: 61): Which forms of ownership, at which level and which local interests should be seen as representative of an 'authentic' and sustainably peaceful polity? Authentic for whom? What ensues when discrepancies 
in this understanding occur? If the principle of local ownership is to be respected, the answer would be as follows: authenticity or local legitimacy should be negotiated and defined by local actors themselves rather than by external actors. This premise deprives the international peacebuilding planners of their power to control the process of hybridisation, which could lead to the emergence of negative forms of peace or illiberal peace (Simangan 2018). Temptation on the part of outside interveners to maintain their influence upon the process and outcome of hybridisation is criticised as a neo-colonial mindset (Richmond 2015: 64). If altruistic external interveners have to let go of their responsibility in helping to establish what Wallensteen (2015) calls 'quality peace' or post-war conditions that make peace sustainable, however, do they enjoy both local and international legitimacy? Are they supposed to be responsible for what is created on the ground in the aftermath of their intervention (Howe et al. 2020)?

These questions bring us back to the dilemma of hybridity. One way for outsiders to circumvent the dilemma is to pursue what Richmond (2015: 60) calls 'positive hybrid forms of peace' that does not include a compromise on the potential emancipatory and empathetic nature of peace. This implies that there is a role and responsibility on the side of external actors to support the genesis of positive forms of hybrid peace. This study argues that 'locally grounded legitimacy' is a key to rescue hybrid peacebuilding from the dilemma. The pursuit of empowering solutions embedded in plurality and relationality is a way forward to achieve 'quality peace'. The real question is: how can altruistic external interveners be connected to the national elite and grassroots stakeholders so that emerging hybrid peace would be based on the locally grounded legitimacy'?

To answer this, functions of mid-space actors are highlighted and investigated in this study. In Asian peacebuilding, outside peacebuilders are often powerless in the face of protected sovereignty as Asian states have sufficient power to exclude or circumvent the external intrusion and usurpation of their national sovereignty (Keethaponcalan 2020). Under such circumstances, outside intervention aiming to bring about changes at the level of grassroots communities seems not feasible. This is why it is essential for outside peacebuilders to establish trust and develop relationships with local mid-space gatekeepers who have access to both the top/national level and the bottom/grassroots level (Uesugi 2020). 
Engagements and interactions in the mid-space are empirically explored in the subsequent case study chapters, in which peacebuilding efforts by China and Japan that do not fit into the Western prototype of liberal peacebuilding are observed. The presence of non-Western donors such as China, Japan, India, South Korea, Indonesia, Malaysia and Singapore has posed an additional complication to Asian peacebuilding ventures in the Philippines, Cambodia, Myanmar, Thailand, Sri Lanka, Nepal and Afghanistan. Having been the victims of Western colonisation and occupation by themselves, they do not necessarily operate in the same way as Western donors nor are they constrained morally by 'universal' norms and 'international' standards defined by the West. This may have unprecedented practical implications for peacebuilding in Asia where non-Western donors such as China are beginning to exert their influence on the practice of peacebuilding and development in the region (Takagi et al. 2019). In this study, therefore, peacebuilding efforts of two major non-Western actors, China and Japan, in several Asian contexts such as Myanmar, Afghanistan, Timor-Leste and Mindanao are reviewed to outline distinctive features of their peacebuilding styles, which so far have not given a high priority to liberal values on recalcitrant local communities (Ghimire 2019: 3), thus effectively avoiding the pitfalls of liberal peacebuilding.

\section{From a Descriptive Lens to an Analytical Tool}

In addition to examining the basic assumptions of hybrid peacebuilding theory, this study embarks on a difficult endeavour to operationalise such theory, advancing the practical utility of 'hybridity' beyond its descriptive power. Existing discussion on hybrid peacebuilding describes the process of hybridisation and possible outcomes of such a process to be a mixture of 'international' and 'local' values. This binary framing of reality has been criticised as will be illustrated in Chapter 2. The variations of international norms and the diversity in historical contexts, cultures, and political landscapes in each setting have suggested that such a binary worldview cripple us to overlook the important dynamism and complexity on the ground. In Chapter 3, complex theory is introduced as an alternative to the binary presumption, offering a more holistic view of the world where a myriad of actors operating in the mid-space are trying to influence the process and shape or reshape the outcome of hybridisation. The process of hybridisation is complex, and its outcome is dependent on unpredictable 
interactions of multiple actors and factors, and thus, a simplistic and static epistemology is problematic. There are hundreds, if not thousands, of different unexpected paths, networks, and nodes that may exist or emerge in the intermediary mid-space.

The introduction of such complexities, however, seems to undermine the goal of operationalising hybrid peacebuilding theory, as it means to transform the theory into a more practitioner friendly and analytically robust tool. Randazzo (2016: 1360) identifies a possible dilemma of operationalising hybrid peacebuilding by saying that when hybridity is used as a tool to uncover unscripted and hidden practices of the everyday, it operates to make the invisible and blurry visible. This, she goes on and argues, runs contrary to the complexity perspective about the process that acknowledges the untraceable links that produce blurred hybrid identities (ibid.). How can such a dilemma be circumvented? Knowing this dilemma, how hybrid peacebuilding theory can better inform the practice of peacebuilding? Is there a way to comprehend dynamic and complex realities in a conceptually manageable manner? What needs to be done to increase the explanatory power of hybrid peacebuilding theory so that external interveners can prepare and equip themselves for more effective assistance?

Finding answers to these difficult but important questions is attempted in Chapter 4 where a typology of mid-space actors is discussed as a step towards operationalising hybrid peacebuilding theory. To solve these puzzles, this study borrows key insights from relevant discourses of relationality, complexity, identity and feminism, and discusses their implications for the operationalisation of hybrid peacebuilding. The typology presented in Chapter 4 helps reflective practitioners to analyse and engage with mid-space actors more effectively. Questions remain unanswered, however, as to how external interveners can design a proper intervention and anticipate their possible impact on the process in the midst of complex exchanges and constantly-changing surroundings. On this point, this study illustrates the utility of relational and systemic approaches, and proposes an alternative to binary, linear and static views of the process of hybridisation. The alternative framework aims to enhance the awareness of external peacebuilders about the local terrain of the relational landscape in which they intervene, and to serve as a set of analytical guidelines to prepare external peacebuilders for supporting efforts of insider-partial mediators to bridge gaps in conflict-affected societies. 


\section{Key Arguments}

The abovementioned theoretical undertakings are complemented by empirical analyses that demonstrate the efficacy of an upgraded hybrid lens. As a prelude to the empirical chapters in this volume, the following highlights the underlying hinges between the following four auxiliary concepts for operationalising the thematic of hybridity and the premises of four case studies of Asian peacebuilding: (1) relationality, (2) complexity, (3) identity, and (4) feminism. Why they are considered pivotal for operationalising hybrid peacebuilding is elaborated below.

\section{Relationality}

Lederach (2005) advocated the need of a Copernican shift from 'knowhow' to 'know-who' in the pursuit of peacebuilding. Building upon his actor-oriented approach, Uesugi (2020) argued that mid-space gatekeepers play key roles in bridging cleavages that exist in society. Uesugi and Kagawa (2020) introduced the concept of 'transformative relationships' as a key indicator for assessing the traits of mid-space gatekeepers who could serve effectively as bridge-builders. This book reiterates this perspective and advances an argument that the nature and magnitude of multidimensional relationships that mid-space actors can cultivate in a given setting is one of the most significant factors explaining the process and outcome of hybrid peacebuilding. As the process of hybridisation is characterised as a journey of constant negotiation and mediation among different stakeholders, an outcome-yet not a terminal —of such a process would be shaped through unregulated and spontaneous interactions among them.

To increase our ability to grasp the dynamic and interactive nature of hybridisation, this study takes two qualitatively different but closely intertwined approaches. The first approach examines power relations among different actors within a complex system. This approach is based on the assumption that any peacebuilding intervention will instigate multiple chain reactions which are unpredictable, and thus denying a simple linear causal attribution to hybrid peacebuilding. At the same time, it assumes that a sound visualisation of power relations among key gatekeepers in the mid-space helps external peacebuilders to navigate in such uncharted waters in the hinterland. The second approach focuses on the identity of 
mid-space actors involved in a peace process. It is based on the assumption that while chain reactions triggered by a series of peacebuilding undertakings in complex systems are hard to predict and control, gatekeepers employ their 'transformative relationships' to bridge existing and emerging gaps in a conflict-affected society so that peacebuilding efforts can bring about 'quality peace'.

Chapter 5 demonstrates that 'transformative relationships' of midspace actors are shaped by their 'identity' vis-à-vis others involved, and the environment in which they operate. Thus the success and failure of bridge-building by particular mid-space actors can be explained partially by their relational identity, i.e., how they see others and how others see them in a given context. Since it is difficult to forecast what sort of chain reactions a certain intervention on a particular relationship can cause, international peacebuilding planners cannot pre-design the course of intervention to induce positive changes in gatekeepers' identity and their perceived identity in a given setting. At the same time, if they presuppose and prepare for the practical necessity of adapting and adjusting constantly to dynamic situations, they may have a better chance of supporting local mid-space actors to nurture their 'transformative relationships' and use them to bridge cleavages in a society. To operate under this premise, outsiders have to be ready to abandon the fixed cookie-cutter blueprint approach merely focusing on a mechanical cause-and-effect analysis applying typical logical frameworks for project formulation. This is one of prescriptive insights that this study presents.

\section{Complexity}

Building upon the perspective of relationality, this study reflects on the momentum that exists in the literature, and applies complexity theory to peacebuilding. Brusset et al. (2016:2) argue that "Complexity may bring new ideas, methods, and tools to peacebuilding practice". According to them, complexity allows us to comprehend how complex systems function and incorporate new realities into our methods, so that we can exert influence more effectively and carefully on such complex systems (ibid.: 3 ). By applying complexity theory to the security sector reform, a particular field of peacebuilding, Ansorg and Gordon (2019: 2) examined the multitude of different actors within and beyond the state, and identified complex patterns of co-operation and contestation within reform initiatives. They concluded that the multiplicity of norms and actors complicated efforts to 
build peace (ibid.). Drawing from the discourse on complexity, they illustrated how proliferation of and contestation between actors, and between their normative positions, may question assumptions of 'success' and 'failure' of international intervention (ibid.: 5).

In Chapter 3, it is argued that the theory of complexity offers a perspective helpful for grasping the dynamic process of hybridisation, one of which is the significance of intersectionality or the nodes of relationships. Uesugi (2020) introduced the notion of a 'dialogue platform' to highlight such intersectionality and examined the roles and functions of mid-space intermediaries who operate as a node, or bridge, which run across different cleavages. This study offers additional insights in the process of hybridisation by employing an innovative approach proposed by de Coning (2018: 317) called 'adaptive peacebuilding' in an effort to operationalise hybrid peacebuilding theory. The insight gained from 'adaptive peacebuilding' is that interplays between international peacebuilders and local stakeholders are iterative processes of mutual learning and adaptation. This premise implies that outsiders have to commit themselves to a long-term engagement in peacebuilding endeavours and be ready to abandon results-based budgeting in which budget formulation is guided by predefined short-term and measurable objectives set by outside interveners to be accountable to their donors, which has prevented international peacebuilders from investing in time-consuming but critical relationship-building with mid-space actors in the hinterland. This is another prescriptive insight presented in this study.

\section{Identity}

What increases the complexity of hybrid peacebuilding is the inclusion of a wide variety of actors who work together to achieve positive peace, suitable and beneficial to all those affected by it. This predisposes hybrid peacebuilding to lay explicit focus on the concept of identity which is intrenched in mid-space gatekeepers partial to the peace process. This study assumes that the path of a peace process is determined, at least in part, by identity factors. This is because in dealing with the complex social reality, people employ 'cognitive fames' to examine, categorise and make sense of the situations and their experiences. Frames define our perceptions, understandings and views of reality, by so doing, they help us systematise our experience and provide normative prescriptions for 
possible actions (Korostelina and Uesugi 2019). It is important to underline that a frame defines not only our ways of interpretation of specific situations but also it decides what particular issues, incidents or conditions receive our attention. Hence, being a social boundary maker, mid-space gatekeepers have the power to set the frames that act as a device to draw borders around what is and is not important (Gardner 2003).

Identity frames include ideas about who they are, what characteristics they share with their group(s) and how they should relate to others (Ibid.). When people view themselves as a part of a larger group, position, institution, or set of values, they behave in ways that protect the markers of this specific identity (ibid.). Gatekeepers who are the guardians of the sense of self (beliefs, values and group affiliations) provide such markers of shared identity or 'identity frames' to their constituencies. Because gatekeepers possess power to impose the shared identity frames on their followers, it makes sense for outside interveners to work with them. In theory, outsiders can expect that gatekeepers exercise their influence to reframe their perceived reality on the ground, and marshal collective support from the grassroots community members for the planned intervention. Because 'identity' is what ties gatekeepers to their followers, it is important for outside interveners to appreciate how gatekeepers' identity affects their preferences, priorities, behaviours and decisions, as their identity and group affiliation influence on how they view and respond to a given situation (ibid.).

A challenge in practice, however, is that gatekeepers are in an inherently difficult position to change their identity as their primary task is to defend their social boundaries. It is true that identity is changeable and under certain circumstances gatekeepers have shifted their dominant identity to serve as bridge-builders. When gatekeepers' identities are threatened or challenged through intervention, they respond normally in ways that reinforce their allegiance to their group affiliations. Although Richmond (2008: 457) argues that hybrid peacebuilding is valued as a realm of complex interconnectedness where multiple actors and networks exist, interact and overlay, "without necessarily resulting in the domination of one core identity or idea", the case study of Cambodian Buddhist monks presented in Chapter 5 demonstrates that under certain conditions it has been proven otherwise. The Cambodian 'peace' monks, whose attributes as gatekeepers stem from their clerical status shared among the affiliated lay followers, revealed that their transformative relationships worked in a horizontal direction but failed in vertical bridge-building. 
While serving as the very source of local and international legitimacy, their primary identity as monks rooted in religious faith and their secondary identity as peace activists limited their flexibility in serving as a vertical bridge-builder whose tasks sometimes compelled them to overstep established Buddhist doctrines and to confront with the authoritarian regime.

As pointed out in Chapter 4 and examined in Chapter 5, identity can serve as both a connector and a divider. Especially in conflict situations, the 'us versus them' frame or the in-group/out-group mindset becomes cognitively prevailing. Under such a psychological condition, while identity serves as a connector that consolidates the shared foundation of an in-group, it has the tendency to act as a divider, deepening the gap between 'us and them'. In theory, gatekeepers have the potential to become a bridge-builder, but in reality it is very difficult for them to uphold the spirit of inclusivity as their primary role as boundary keepers forces them to draw a line between them and their adversaries. The identity of gatekeepers can work against what hybrid peacebuilding advocates for: blurring identity boundaries and fostering interconnectedness and plurality (Randazzo 2016: 1356). Nevertheless, gatekeepers can become bridge-builders in a conducive environment in which they maintain firm grips on their followers by framing their expectations and addressing and their needs.

Given the fluid and complex nature of identity that influences the processes and outcomes of hybridisation, identity frames can turn into either tools or obstacles for gatekeepers depending on the circumstance. It is therefore argued in this study that identity is a key factor that affects the condition for gatekeepers to reach beyond their in-group and conduct bridge-building across social boundaries. Gatekeepers may commit themselves to either bridge-building or spoiling, depending on the context in which their overriding identity is perceived and defined. Outside intervenors should not be surprised at the act of spoiling committed by gatekeepers nor should they be disguised by a superficial and static identity of gatekeepers as it is variable. Upon facing spoiling repercussions on the peace process, outside interveners might have to reconsider and adjust their approach, rather than trying to dissuade gatekeepers from spoiling. As Chapter 4 suggests the act of spoiling can be regarded as an opportunity for outside interveners to meet the requirements for being granted a locally grounded legitimacy. This assumption guides outside peacebuilders to a more inclusive and adaptive practice of peacebuilding, 
urging them to extend their reach to a wide range of mid-space actors. Upon intervention, peacebuilders have to be aware of their epistemological prejudice (including cultural, linguistic and professional ones) as well as their predisposed habit of labelling stakeholders and being selective about whom they work with. Their stakeholder mapping and analysis must reflect the dynamic and complex nature of the reality, paying special attention to the power of identity. This is the third prescriptive insight presented in this study.

\section{Feminist's Perspective}

When focusing on relational and actor-based approaches to peacebuilding, hybrid peacebuilding theory offers a useful lens and a practical tool. However, hybrid peacebuilding approaches tend to focus on influential players both at local and international levels in negotiating, mediating, defining and refining the emerging hybrid order and peace, and they tend to neglect other actors who have very limited influence upon the peace process. By criticising conventional approaches, feminists underline the importance of including marginalised and minority groups as well as moving away from lingering colonial attitudes in the peace process. As highlighted in Chapter 2, feminists argue strongly for the establishment of a positive peace and the eradication of those illiberal structural factors which could endure into the post-conflict orders and hierarchies.

In Chapter 5, a special attention is paid to Cambodian 'peace' monks who constitute a minority group in the Buddhist clerical community (in terms of not following the mainstream, state-centric Buddhist's teaching), and their effectiveness as bridge-builders is assessed by the function that their paramount identity played. On the issue of representation for marginalised groups of people, pitfalls or dangers of hybrid peacebuilding are identified in the structure of multi-track peacebuilding. A sub-national minority who lives along with a national-level minority is often not included in the peace process as traditional approaches to peacemaking have focused on incumbent-insurgency confrontation at the national level (Wilson 2020). Indigenous Peoples in Mindanao are a case in point, which is covered in Chapter 6. Being non-Muslim sub-national minority residents in Mindanao caught in the midst of war of national liberation fought by a national-level minority of Muslims called Moros against the government of the Philippines, Indigenous Peoples were often marginalised in the 'Bangsamoro' peace process. Likewise, women, 
youth and poor are often not included in traditional peace processes. By unpacking the concept of civil society and analysing empirically the roles and functions played by civil society organisations in Mindanao, Chapter 6 sheds light on the conventionally silenced group of people, and discusses that civil society organisations served as a vehicle promoting Indigenous People's participation and women empowerment. It demonstrates that perspectives of Indigenous People were included in the peace process by utilising civil society organisations as a platform and employing relevant international trends and norms to legitimise their views.

\section{Eastphalian Hybrid Peacebuilding}

This study is a response to emerging interests in peacebuilding actors in Asia and the impact their practice has on the existing liberal order, which is built upon the Western values and practices. In other words, it contributes to a debate about whether 'Eastphalian' orders (Kim 2009) are emerging as alternative narratives on hybrid peacebuilding by examining approaches taken by two dominant regional powers in Asia, China and Japan, in Chapters 7 and 8 respectively. Following the footsteps established by the companion volume, Hybrid Peacebuilding in Asia (Uesugi 2020), knowledge gaps in the discourse on hybrid peacebuilding are bridged in this study by providing case studies of Asian-led peacebuilding.

A key added-value of this study, therefore, is to share empirical analyses of the peacebuilding practice in Asia so far overlooked by the Western scholarship on peacebuilding, in which Asian contexts are treated as subjects of peacebuilding intervention such as Cambodia, Myanmar, Mindanao, Nepal, Timor-Leste, Afghanistan, Sri Lanka, Thailand, Aceh (Indonesia) to name but a few (Uesugi 2014). In contrast, this study sheds light on Asian peacebuilders and examines their efforts on the ground, exploring their potential as a 'hybrid peacebuilding facilitator' (Uesugi 2018). In English language literature, Japanese approaches to peacebuilding have been covered mainly by Japanese (Tatsumi 2016; Tatsumi and Kennedy 2017) and scholars from Asia such as Lam (2009) from Singapore. Attention paid to Chinese approaches to peacebuilding is a relatively recent phenomena as many of the academic work on China focuses on China's peacekeeping (Lanteigne and Hirono 2012) or the Belt and Road Initiative, a notable exception is the report of the Saferworld entitled China and conflict-affected states (Campbell et al. 2012). Thus, this book contributes to filling the gap in the existing literature. 
Another added value of this study is that, through empirical studies of the Chinese and Japanese peacebuilding efforts, it offers a way to improve current models of peacebuilding. The findings of these case studies suggest that their approaches, while sharing many similarities, have distinctive features between them and between them and liberal peacebuilding approaches. Both China and Japan prefer to operate under the Westphalian principles of respecting sovereignty and avoiding forceful military intervention. At the same time, however, they both have attempted innovative undertakings that deserve more than a pacing notice in the literature and practice of hybrid peacebuilding, which will be elaborated in Chapters 7 and 8 .

\section{STRuCture OF THE BoOK}

This book has five components. This introductory chapter and the subsequent literature review chapter serve as a backgrounder to this study. The second part encompasses two conceptual chapters laying the theoretical foundations of this study by introducing concepts such as complexity, adaptive peacebuilding, mid-space actors and gatekeepers. The following two chapters constitute the third component that offers both theoretical discussion and empirical analysis focusing Cambodia and Mindanao, providing insider's perspective on hybrid peacebuilding. The next section, which includes two empirical chapters focusing on peacebuilding efforts of China and Japan as outsiders, outlines the main features of these approaches from an angle of hybrid peacebuilding. Finally, the concluding chapter synthesises the key findings and arguments. Before closing this introductory chapter, a set of previews of the subsequent chapters are provided as follows.

Chapter 2: A Brief Sketch of Hybrid Peacebuilding by Uesugi, Deekeling and Ingstedt connects hybrid calls and relevant criticisms to the development of peacebuilding debates at large. It briefly presents ontological aspects of peacebuilding, as they may be found both in academia and practice. It also explains core arguments in favour of adopting hybrid peacebuilding, and shows how the concept of hybridity has been criticised in the discourse of peacebuilding both within its own circles and by others. Showcasing the various sides of peacebuilding, and hybridity specifically, this literature review chapter sets the stage for a new set of discussions in the subsequent chapters. 
Chapter 3: Hybridity, Adaptive Peacebuilding and Complexity by de Coning and McDonald-Colbert makes the case for the inclusion of a complexity ontology and an adaptive methodology into the hybrid peacebuilding debate. International peacebuilders can assist and facilitate the voluntary emergence of self-sustainable and resilient social institutions through the peace process, but if they interfere too much, they would undermine the self-organising processes necessary to sustain resilient social institutions. Based on this premise, this chapter introduces 'adaptive peacebuilding' to address the dilemma of hybrid peacebuilding, by so doing it contributes to operationalising hybrid peacebuilding theory. It provides a conceptual guidelines with an adaptive methodology where peacebuilders engage actively in a process to sustain peace and resolve conflicts by employing an iterative process of learning and adaptation. It argues that a complexity informed approach to hybrid peacebuilding can safeguard, stimulate, facilitate and create the space for societies to develop resilient capacities for self-organisation.

Chapter 4: Bridging Gaps: From a Descriptive to a Practical Mid-Space Actor Typology? by Deekeling and Simangan puts forward an argument that the concept of hybridity sheds light on the complexity of conflict settings. Hybridity as a lens helps to analyse the participation of all actors involved and entangled in a social network of normative and political power, while avoiding theoretical binaries that oversimplify the process of post-conflict peacebuilding. The chapter stresses that what lacks is a practical application of hybridity in peacebuilding that engages actively with bottom/local or grassroots, top/national and international actors through mediation in the mid-space to create sustainable peace. Given this practical shortcoming of hybridity, a conceptual review of midspace actors as gatekeepers and their capacities to enable dialogue among opposing parties are presented. It offers an analytical frame for investigating the encounters between insider-partial mediators and outside peacebuilders in and around the mid-space, which is applied to the subsequent empirical chapters.

Chapter 5: The Power of Identity in Hybrid Peacebuilding: Buddhist Monks in Post-Conflict Cambodia by Umeyama and Brehm connects the concept of identity to mid-space actors involved in hybrid peacebuilding. The power of identity draws attention to the process of framing and othering as important factors contributing to successful bridge-building across diverse actors during hybrid peacebuilding. This chapter focuses on the role of identity of Buddhist monks in Cambodia, and examines how 
and why they both succeeded and failed in their roles as bridge-builders. It is argued that identity frames and networks of mid-space actors predispose them to excel in particular fields and fail in others. Through the case study of Cambodian 'peace' monks, it demonstrates that the concept of identity serves as an useful indicator for explaining why and how a mid-space actor may transform from being a bridge-builder into a spoiler during the peacebuilding process.

Chapter 6: Frictional Binaries: Hybridity, Civil Society, and LiberalLocal Peacebuilding in Mindanao by Manaysay and Espesor argues that the concept of hybrid peacebuilding has highlighted the need to empower local civil society groups. Using examples from Mindanao, this chapter contends that the debates on liberal-local hybridity can most meaningfully gain from asking questions not only about the processes of internationalisation and localisation, but also about the ways in which hybrid mechanisms are able to produce more or less stable outcomes. By turning into the agency of civil society actors, it suggests that the concept of hybridity, which is often represented using dichotomised categories such as 'liberal-international' and 'illiberal-local', tends to oversimplify the conceptual intricacies and dynamic processes between top-down and bottom-up approaches. The analysis in the chapter illustrates the manner civil society actors are able to negotiate their complexities within the frictional binaries of liberal ideas, institutions and resources vis-à-vis local practices, power relations and norms.

Chapter 7: Rise of China's Developmental Peace: Prospects for Asian Hybrid Peacebuilding by Wong and Li claims that without a clear peacebuilding policy at home, China does not take a systematic and unified approach to peacebuilding, although its 'developmental peace' has many traits that resemble the pursuit of hybrid and adaptive peacebuilding undertaken to compensate for the shortcomings of liberal peacebuilding. This chapter demonstrates how China has approached to conflict-affected societies in Asia, especially their mid-space actors, and how the Belt and Road Initiative has been employed to generate a synergy with 'developmental peace' by providing economic incentives to gatekeepers such as armed ethnic groups in Myanmar and the Taliban in Afghanistan. While the chapter identifies the shortcomings of China's approach, it maintains that China's 'developmental peace' can be regarded as a form of hybrid peacebuilding with 'Chinese characteristics' and be an alternative to liberal peacebuilding. 
Chapter 8: Japan's Peacebuilding and Mid-Space Actors: A Bridge between the West and the Rest by Uesugi and Deekeling examines Japan's peacebuilding assistance in conflict-affected societies in Asia, and assesses Japan's potential to emerge as a hybrid peacebuilding facilitator. By reviewing Japan's flagship projects in Timor-Leste, Myanmar and Mindanao, the chapter shows that Japan holds the ability to establish trust-relationships with top/national leaders of the aid-recipient countries through apolitical, non-intrusive and long-term approaches that Japanese actors display. It demonstrates that how Japanese actors have developed relationships with mid-space actors in conflict-affected societies where and when access of other donors were denied. While the chapter identifies several shortcomings of the Japanese approach such as the limited inclusion of stakeholders and unequal distribution of peace dividend, it concludes that Japan can emerge as a hybrid peacebuilding facilitator if these shortcomings are addressed.

Chapter 9: Conclusion by Uesugi, Deekeling, Umeyama and McDonald-Colbert summarises the findings of the previous chapters and presents the harnessing arguments among them. The goal is to evaluate whether or not the existing gap between hybrid peacebuilding theory and its operationalisation has been successfully closed. It reiterates the key points of the study by using a complexity-informed framework and revisiting the mid-space actor typology that is proposed as a link between the analytical framework and the practical application. It concludes that mid-space actors could provide a viable focal point in encouraging the establishment of self-resilient social institutions from within without dictating the content of such emergencies.

\section{REFERENCES}

Ansorg, N., \& Gordon, E. (2019). Co-operation, Contestation and Complexity in Post-Conflict Security Sector Reform. Journal of Intervention and Statebuilding, 13(1), 2-24.

Bargués-Pedreny, P., \& Randazzo, E. (2018). Hybrid Peace Revisited: An Opportunity for Considering Self-governance? Third World Quarterly, 39(1), $1543-1560$.

Berreby, D. (2008). Us and Them. Chicago: University of Chicago Press. Brusset, E., de Coning, C., \& Hughes, B. (Eds.). (2016). Complexity Thinking for Peacebuilding Practice and Evaluation. London: Palgrave Macmillan. 
Campbell, I., Wheeler, T., Attree, L., Butler, D. M., \& Mariani, B. (2012). Conflict and Conflict-affected States: Between Principle and Pragmatism. Saferworld. https://www.ecosonline.org/reports/2012/Saferworld_C hina_and_conflict-affected_states.pdf.

Clements, K. P., \& Uesugi, Y. (2020) Chapter 7 Conclusion. In Y. Uesugi (Ed.), Hybrid Peacebuilding in Asia (pp. 139-152). Cham: Palgrave Macmillan.

de Coning, C. (2013). Understanding Peacebuilding as Essentially Local. Stability: International Journal of Security and Development, 2(1), 1-6.

de Coning, C. (2018). Adaptive peacebuilding. International Affairs, 94(2), 301-317.

Donais, T. (2012). Peacebuilding and Local Ownership: Post-conflict Consensusbuilding. London: Routledge.

Gardner, R. (2003). Identity Frames. In G. Burgess \& H. Burgess (Eds.), Beyond Intractability. Boulder: Conflict Information Consortium, University of Colorado. http://www.beyondintractability.org/essay/identity-frames.

Ghimire, S. (2019). The Politics of Peacebuilding: Emerging Actors and Security Sector Reform in Conflict-Affected Sates. London: Routledge.

Howe, B. (2018). Chapter 1: State-Centric Challenges to Human-Centred Governance. In B. Howe (Ed.), National Security, Statecentricity, and Governance in East Asia (pp. 1-14). Cham: Palgrave Macmillan.

Howe, B., Peou, S., \& Uesugi, Y. (2020). UN Governance: Peace and Human Security in Cambodia and Timor-Leste. Cham: Palgrave Macmillan.

Keethaponcalan, S. I. (2020). Chapter 2 Asian Peacebuilding: Theory and Practice. In Y. Uesugi (Ed.), Hybrid Peacebuilding in Asia (pp. 15-35). Cham: Palgrave Macmillan.

Kim, S. (2009). Eastphalia Rising: An Enquiry into the Emergence of Asian Perspective on International Law and Global Governance (Unpublished J.S.D. thesis). Indiana University.

Korostelina, K., \& Uesugi, Y. (2019, March). Perception of Korean Reunification Among Japanese Experts: The Collective Frame Approach. WIAS Research Bulletin, 11, 5-16.

Lam, P. E. (2009). Japan's Peace-Building Diplomacy in Asia: Seeking a More Active Political Role. Oxon and New York: Routledge.

Lanteigne, M., \& Hirono, M. (Eds.). (2012). China's Evolving Approach to Peacekeeping. New York: Routledge.

Lederach, J. P. (2005). The Moral Imagination. New York: Oxford University Press.

Lee, S. (2019). Local Ownership in Asian Peacebuilding: Development of Local Peacebuilding Models. Cham: Palgrave Macmillan.

Lee, S. (2020). Reflection on the "Local Turn" in Peacebuilding: Practitioners' View. Journal of Human Security Studies, Special Issue, 1, 25-38. 
Lee, S., \& Özerdem, A. (Eds.). (2015). Local Ownership in International Peacebuilding: Key Theoretical and Practical Issues. London: Routledge.

Mac Ginty, R., \& Richmond, O. P. (2013). The Local Turn in Peace Building: A Critical agenda for Peace. Third World Quarterly, 34(5), 763-783.

Mac Ginty, R., \& Richmond, O. (2016). The Fallacy of Constructing Hybrid Political Orders: A Reappraisal of the Hybrid Turn in Peacebuilding. International Peacekeeping, 23(2), 219-239.

Randazzo, E. (2016). The Paradoxes of the 'Everyday': Scrutinising the Local Turn in Peace Building. Third World Quarterly, 37(8), 1351-1370.

Richmond, O. P. (2008). Reclaiming Peace in International Relations. Millennium, 36(3), 439-470.

Richmond, O. P. (2015). The Dilemmas of a Hybrid Peace: Negative or Positive? Cooperation and Conflict, 50(1), 50-68.

Simangan, D. (2018). When Hybridity Breeds Contempt: Negative Hybrid Peace in Cambodia. Third World Quarterly, 39(8), 1525-1542.

Takagi, Y., Kanchoochat, V., \& Sonobe, T. (Eds.). (2019). Developmental State Building: The Politics of Emerging Economies. Singapore: Springer.

Tatsumi, Y. (Ed.). (2016). Japan as a Peace Enabler: Views from the Next Generation. Washington, DC: The Stimson Center.

Tatsumi, Y., \& Kennedy, P. (Eds.). (2017). Peacebuilding and Japan: Views from the Next Generation. Washington, DC: The Stimson Center.

Uesugi, Y. (Ed.). (2014). Peacebuilding and Security Sector Governance in Asia. Zürich: LIT.

Uesugi, Y. (2018). Chapter 4 Platforms for Dialogue and Hybrid Facilitators in the Bangsamoro Peace Process. In M. Yamada \& M. Honda (Eds.), Complex Emergencies and Humanitarian Response (pp. 65-86). Osaka: Union Press.

Uesugi, Y. (Ed.). (2020). Hybrid Peacebuilding in Asia. Cham: Palgrave Macmillan.

Uesugi, Y., \& Kagawa, M. (2020). Chapter 3 A Typology of Mid-Space Local Bridge-Builders. In Y. Uesugi (Ed.), Hybrid Peacebuilding in Asia (pp. 3760). Cham: Palgrave Macmillan.

Wallensteen, P. (2015). Quality Peace: Peacebuilding, Victory, and World Order. New York: Oxford University Press.

Wilson, C. (2020) Chapter 6 Illiberal Peacebuilding in India and Indonesia: The Dangers of the Hybrid Approach. In: Y. Uesugi (Ed.), Hybrid Peacebuilding in Asia (pp. 115-138). Cham: Palgrave Macmillan. 
Open Access This chapter is licensed under the terms of the Creative Commons Attribution 4.0 International License (http://creativecommons.org/licenses/ by $/ 4.0 /$ ), which permits use, sharing, adaptation, distribution and reproduction in any medium or format, as long as you give appropriate credit to the original author(s) and the source, provide a link to the Creative Commons license and indicate if changes were made.

The images or other third party material in this chapter are included in the chapter's Creative Commons license, unless indicated otherwise in a credit line to the material. If material is not included in the chapter's Creative Commons license and your intended use is not permitted by statutory regulation or exceeds the permitted use, you will need to obtain permission directly from the copyright holder.

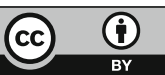

